\title{
Grooves surrounding the micropyle decrease the inseminating dose in fish
}

\author{
Matheus Pereira-Santos ${ }^{1}$, Eduardo Shimoda ${ }^{3}$, André Furugen Cesar de Andrade ${ }^{4}$, \\ Luciano Andrade Silva ${ }^{4}$, Takafumi Fujimoto ${ }^{5}$, José Augusto Senhorini ${ }^{6}$, George Shigueki Yasui ${ }^{4}$ \\ and Laura Satiko Okada Nakaghi ${ }^{2}$ \\ Aquaculture Center, São Paulo State University, Jaboticabal-SP, Brazil; Department of Pharmacy, Cândido Mendes \\ University, Campos dos Goytacazes, Brazil; Department of Veterinary, University of São Paulo, Pirassununga, Brazil; Faculty \\ of Fisheries Sciences, Hokkaido University, Hakodate, Japan; and National Center for Research and Conservation of \\ Continental Fish, Chico Mendes Institute of Biodiversity Conservation, Pirassununga, Brazil
}

Date submitted: 04.08.2017. Date revised: 04.08.2017. Date accepted: 21.10.2017

\section{Summary}

In fish with external fertilization, sperm must reach the oocyte through the micropyle to enter the cytoplasm. Fertilization success is then influenced by characteristics of oocytes or sperm. In this study, we evaluated oocyte morphology and sperm motility parameters and their effects on the inseminating dose in a teleost fish Astyanax altiparanae. Interestingly, we found one of the lowest yet described inseminating doses in teleosts (2390 spermatozoa oocyte $\mathrm{ml}^{-1}$ ). Such a fertilization efficacy may be explained by the long duration of sperm motility $(>75 \mathrm{~s})$, the small oocyte diameter $(695.119 \mu \mathrm{m})$, large micropyle diameter $(7.57 \mu \mathrm{m})$, and the presence of grooves on the oocyte surface that guides spermatozoon to the fertilization area. Additionally, we have described for the first time a structure that combines grooves on the chorion surface and a ridge in the micropylar area.

Keywords: Fertilization, Gametes, Morphology, Sperm, Teleosts.

\footnotetext{
${ }^{1}$ All correspondence to: Matheus Pereira-Santos. Aquaculture Center, São Paulo State University, Via de Acesso Prof. Paulo Donato Castellane s/n, 14884-900, Jaboticabal-SP, Brazil. E-mail: matheusps.pereira@gmail.com

${ }^{2}$ Aquaculture Center, São Paulo State University, Via de Acesso Prof. Paulo Donato Castellane s/n, 14884-900, Jaboticabal-SP, Brazil.

${ }^{3}$ Department of Pharmacy, Cândido Mendes University, Rua Anita Peçanha, 100, 28030-335, Campos dos Goytacazes-RJ, Brazil.

${ }^{4}$ Department of Veterinary, University of São Paulo, Avenida Duque de Caxias Norte, 225, 13630-080,

Pirassununga-SP, Brazil.

${ }^{5}$ Faculty of Fisheries Sciences, Hokkaido University, 3-1-1

Minato-cho, 041-8611, Hakodate, Japan.

${ }^{6}$ National Center for Research and Conservation of Continental Fish, Chico Mendes Institute of Biodiversity Conservation, Rodovia Pref. Euberto Nemésio Pereira de Godoy, Km 6, 5, CP 65, 13.630-970. Pirassununga, São Paulo, Brazil.
}

\section{Introduction}

The control of fish reproduction is a key issue for both basic and applied developmental sciences. One of the first steps to manipulate fish reproduction is to understand the mechanisms involving sperm-oocyte interactions that result in fertilization and subsequent embryo development. This information is important to achieve good fertilization rates (Bobe \& Labbé, 2010). Successful fertilization in teleost fish depends on a complex chain of adaptive mechanisms and speciesspecific sperm-oocyte interactions. The main steps during fertilization process include: (1) activation of sperm motility and reaching the oocyte; (2) entrance of spermatozoon through the micropyle; (3) binding of sperm to the oocyte surface; (4) penetration of sperm into the ooplasm; (5) fusion of the pronuclei of the oocyte and sperm; and (6) activation of the oocyte and embryonic development (Coward et al., 2002; Hirohashi et al., 2008). The stage at which the sperm enters the ooplasm is one of the critical steps in 
development and is conditioned by sperm and oocytes characteristics.

Teleost oocytes present a single micropyle, which is a small channel that provides external access to the ooplasm. The small inner diameter of the micropyle permits a single spermatozoon to penetrate and achieve fertilization, and then closes preventing polyspermy. Additional mechanisms that prevent polyspermy also occur, such as the cortical reaction, increase in the perivitelline space, and formation of the fertilization cone (Ginsburg, 1961, 1963; Coward et al., 2002; McMillan, 2007).

Fertilization success is also affected by sperm quality. In fish, the fertilization ability of the spermatozoan is measured a priori by motility. Parameters regarding motility are well known to correlate with fertilization success, including the percentage of motile spermatozoa and other motility traits (Stolz \& Neff, 2006; Rudolfsen et al., 2008). The duration of sperm motility is important, because the length of this parameter is normally very short for the majority of freshwater teleosts as observed in salmonids (30 s; Scott \& Baynes, 1980; Morisawa \& Morisawa, 1986), catfish (30-40 s; Mansour et al., 2002), and characids (40-90 s for most of species; Viveiros \& Godinho, 2009).

Fertilization success is also influenced by the interaction between oocytes and sperm. The amount of sperm necessary to maximize the fertilization rates (inseminating dose) depends on the characteristics of the gametes, including the diameter of the oocyte and sperm motility. In teleosts, the inseminating dose was evaluated in some species including Brycon insignis (314,481 spermatozoa per oocyte; Shimoda et al., 2007), Misgurnus anguillicaudatus $(687,65$ spermatozoa per oocyte; Yasui et al., 2009), Clarias gariepinus (15,000 spermatozoa per oocyte; Rurangwa et al., 1998) and Oncorhynchus mykiss (200,000 spermatozoa per oocyte; Silveira et al., 1988). However, such variation among species is not fully understood, although some authors have hypothesized that egg diameter and motility parameters are the main factors affecting inseminating dose.

This study aimed to evaluate inseminating dose and its relationship with oocyte ultrastructural and sperm motility analysis parameters in a teleost fish. We used the yellowtail tetra Astyanax altiparanae (Garutti \& Britski, 2000) as a model.

\section{Materials and methods}

All procedures were performed in agreement with the Guide for the Care and Use of Laboratory Animals of University of São Paulo, Brazil.

\section{Gamete sampling and fertilization}

All fertilization procedures and gamete handling were performed according to our previous work (Yasui et al., 2015). Briefly, fish were induced to spawn using a single dose of Ovopel [(D-Ala $\left.{ }^{6}, \mathrm{Pro}^{9}-\mathrm{NEt}\right)-$ $\mathrm{mGnRH}+$ metoclopramide] (3 $\mathrm{mg}$ of pellet $\mathrm{kg}^{-1}$ for males and females) and then maintained in a 200 $\mathrm{L}$ tank at $25-30^{\circ} \mathrm{C}$. Gametes were sampled $10-12 \mathrm{~h}$ afterwards. Fish were anesthetized with menthol at $0.1 \mathrm{mg} \mathrm{L}^{-1}$ and the genital area was carefully dried. Sperm sampling was achieved by stripping and the sperm was immediately collected using a $1000 \mu \mathrm{l}$ Eppendorf micropipette (Eppendorf, Germany). The sampled sperm was transferred to a $1.5 \mathrm{ml}$ tube containing $400 \mu \mathrm{l}$ of modified Ringer solution (128.3 $\mathrm{mM} \mathrm{NaCl}, 23.6 \mathrm{mM} \mathrm{KCl}, 3.6 \mathrm{mM} \mathrm{CaCl}, 2.1 \mathrm{mM}$ $\mathrm{MgCl}_{2}$ ) and homogenized by gentle pipetting. This solution maintains the viability of the sperm up to 3 days at $2.5^{\circ} \mathrm{C}$ (Yasui et al., 2015). After each sampling, we immediately measured sperm motility and sperm concentration using a haemocytometer.

Oocytes were stripped on a $100 \mathrm{~mm}$ Petri dish covered by a plastic film (Saran wrap) and then used for fertilization trials. All procedures were performed at room temperature $\left(\sim 27^{\circ} \mathrm{C}\right)$.

\section{Evaluation of inseminating dose}

Oocytes were pipetted (50 $\mu \mathrm{l}, 295.2 \pm 7.4$ oocytes) into six Petri dishes (100 mm diameter) covered by a plastic film (Saran wrap) using a $200 \mu$ l cut tip (inner diameter $3 \mathrm{~mm}$ ). After pipetting, each egg mass was immediately inseminated with $50 \mu$ of diluted sperm. The sperm was diluted using Ringer's solution to give concentrations of 28,125, 56,250, 112,500, 225,000, 450,000 and 1,125,000 spermatozoa per $\mathrm{ml}$.

After insemination, the gametes were activated by addition of $950 \mu \mathrm{l}$ distilled water, and the mixture on the Petri dish was immediately homogenized vigorously by hand for $30 \mathrm{~s}$. Dilution with water gave rise to inseminating doses of 100, 200, 400, 800, 1600 and 10000 spermatozoa per oocyte $\mathrm{ml}^{-1}$ (four replications for each dose were done). Considering the variation in the number of oocytes pipetted in each replication, the insemination dose was individually analyzed for each sample.

\section{Evaluation of sperm motility using CASA analysis}

In this experiment, we used sperm samples from five adult males $(\mathrm{SL}=6.8 \pm 0.72 \mathrm{~cm}$; $\mathrm{TW}=19.697$ $\pm 3.04 \mathrm{~g}$ ). For evaluation of sperm motility, we used an automated system Sperm Class Analyzer $\mathrm{SCA}^{\circledR}$ (Microptic, Barcelona, Spain) connected to a microscope (Nikon NI, Tokyo, Japan). In order to 
measure the sperm motility in our studying species, we set the software using the following parameters:

1. particle area: $2-90$ microns $^{2}$;

2. progressivity: $80 \%$ of STR;

3. circular: $50 \% \mathrm{LIN}$;

4. connectivity: 14 ;

5. VAP points: 5 ;

6. warning to six fields;

7. containing 5000 sperms;

8. $20 \%$ concentration;

9. images in the report: 15 ;

10. number of images: 25 ;

11. images per second: 24 ;

12. slow $<2$ microns $\mathrm{s}^{-1}$;

13. medium $<5$ microns s $^{-1}$;

14. rapid $<15$ microns $\mathrm{s}^{-1}$.

One microlitre of sperm was placed on a Makler chamber (Selfi-Medical Instruments, Haifa, Israel) previously coated with bovine serum albumin (BSA) at $0.1 \%$. The sperm was then activated by 30 -fold dilution with distilled water and motility parameters were measured at $15,30,60,90,120$ and 135 s postactivation.

We measured the following parameters: linearity (LIN); beat cross-frequency (BCF); amplitude of lateral head (ALH); curvilinear velocity (VCL); straight line velocity (VSL); average path velocity (VAP); wobble (WOB); and straightness (STR).

\section{Scanning electron microscopy oocyte analysis}

The samples were fixed in Karnovsky solution (2.5\% glutaraldehyde $+2.5 \%$ paraformaldehyde) and postfixed in osmium tetroxide at $1 \%$ for $2 \mathrm{~h}$, washed in $0.1 \mathrm{M}$ sodium phosphate buffer $\mathrm{pH} 7.4$, and then dehydrated in a graded series of ethanol. Then the samples were dried at the critical point in a dryer with liquid $\mathrm{CO}_{2}$, the samples were mounted onto stubs and coated in gold-palladium ions (Denton Vacuum Desk II), and subsequently scanned in a scanning electron microscope (SEM: Jeol - JSM 5410, Akishima, Tokyo, Japan).

\section{Statistics}

Data are shown as mean \pm standard error. Regression analysis was performed to estimate the inseminating dose using a 'linear response plateau' model. Sperm parameters were checked for normal distribution using the Lilliefors' test and then compared USING analysis of variance (ANOVA) followed by Tukey multiple range test. The statistical analyses were performed using SAEG 9.1 and Statistica 10 for Windows ${ }^{\circledR}$ at a probability of 0.05 .

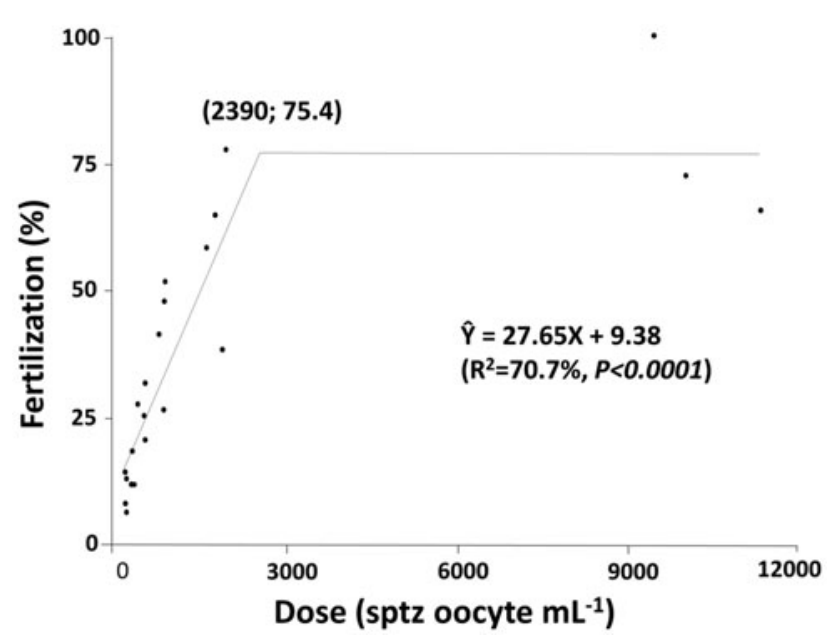

Figure 1 Insemination dose of Astyanax altiparanae. The results indicated that an insemination dose above 2390 sperm per oocyte does not increase fertilization rates above $75.4 \%$.

\section{Results}

\section{Inseminating dose}

Regression analysis of the inseminating dose is shown on Fig. 1 and revealed that an increase in insemination dose promotes a linear increase in the fertilization rate up to a concentration of 2390 spermatozoa per oocyte per $\mathrm{ml}$; at this point the fertilization rate was maximum, reaching $75.4 \%$. After this point, the fertilization rate reached a 'plateau' in which an increase in insemination dose did not affect the fertilization rates (Fig. 1).

\section{Sperm motility}

Sperm motility of Astyanax altiparanae is shown on Fig. 2. A quantitative analysis expressed by total motility, including all the motile cells, revealed that the sperm motility at $15 \mathrm{~s}$ after activation was $83.9 \pm 3.1 \%$ and decreased significantly to $54.5 \pm 5.5 \%$ only at 45 $\mathrm{s}(P=0.0020)$. However, a more detailed analysis of sperm velocities indicated a rapid decrease in sperm quality. A general analysis of sperm motility indicates that the percentage of rapid progressive cells decreased abruptly $(P=0.0005)$ from $15 \mathrm{~s}(54.1 \pm 3.3 \%)$ to $30 \mathrm{~s}$ $(33.3 \pm 2.0 \%)$. At $75 \mathrm{~s}$, the percentage of sperm motility decreased to $29.4 \pm 2.9 \%$ with predominantly 'slow' cells $(26.1 \pm 2.6 \%)$ and also non-motile cells $(61.9 \pm$ $8.7 \%$ ). In agreement with these data, a decrease in velocity parameters was found from 15 to $30 \mathrm{~s}$ on curvilinear velocity (VCL) $\left(20.1 \pm 1.9 \mu \mathrm{m} \mathrm{s}^{-1}\right.$ to $11.9 \pm$ $\left.1.4 \mu \mathrm{m} \mathrm{s}^{-1}, \mathrm{P}=0.0005\right)$, progressive linear velocity (VSL) $\left(16.2 \pm 1.7 \mu \mathrm{m} \mathrm{s}^{-1}\right.$ to $\left.9.2 \pm 1.3 \mu \mathrm{m} \mathrm{s}^{-1}, P=0.0008\right)$ and average velocity of trajectory (VAP) $\left(18.5 \pm 1.8 \mu \mathrm{m} \mathrm{s}^{-1}\right.$ to 

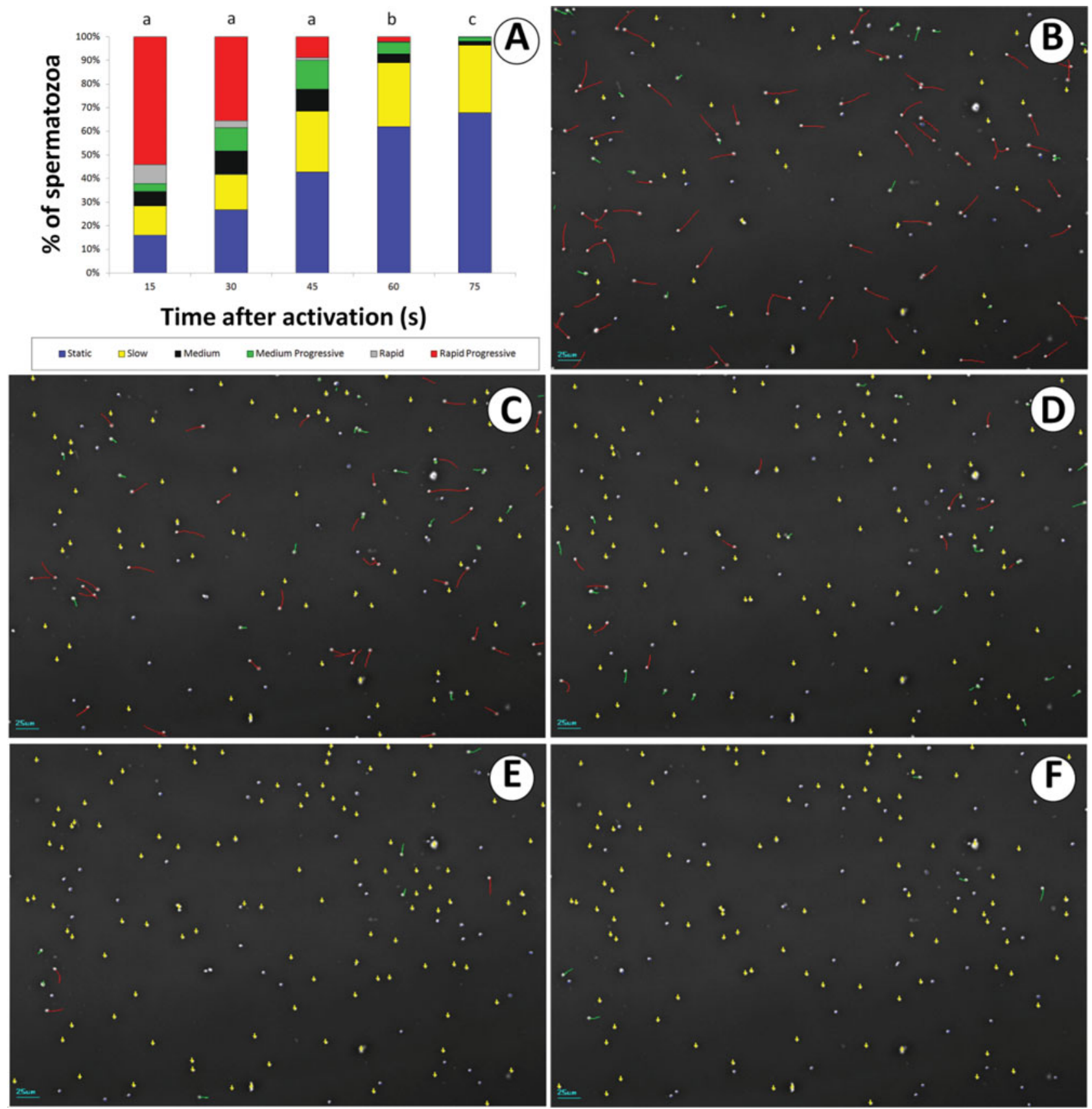

Figure 2 Sperm motility of Astyanax altiparanae. Types of motility $(A)$ measured at $15 \mathrm{~s}(B), 30 \mathrm{~s}(C), 45 \mathrm{~s}(D), 60 \mathrm{~s}$ $(E)$ and $75 \mathrm{~s}(F)$ post-activation. On the right, spermatozoa traces during motility evaluation emphasizing all the cells recognized and analyzed by the software. Spermatozoa were classified as fast progressive (red traces, $>15$ microns s$^{-1}$ ), medium progressive (green traces, $<5$ microns s${ }^{-1}$ ), slow movement (yellow traces, $<2$ microns $\mathrm{s}^{-1}$ ) and non-motile cells (blue dots).

$\left.10.8 \pm 1.3 \mu \mathrm{m} \mathrm{s}^{-1}, P=0007\right)$. Beat cross-frequency (BCF) also decreased from $4.5 \pm 0.3$ beats $\mathrm{s}^{-1}$ at $15 \mathrm{~s}$ to $3.1 \pm 0.3$ beats $\mathrm{s}^{-1}(P=0.0034)$. This variation is also expressed on the motility analysis showing sperm traces (Fig. 3A$H$ ). At $15 \mathrm{~s}$ (Fig. 2B), predominantly rapid progressive cells (red traces) were found but at $75 \mathrm{~s}$ (Fig. $2 F$ ) most of the cells were static (blue dots) and slow cells (yellow traces).

Parameters related to linearity were maintained for longer periods. Linearity (LIN) (Fig. 3D) decreased from $61.6 \pm 3.2 \%$ at $15 \mathrm{~s}$ to $33.8 \pm 6.7 \%$ at $45 \mathrm{~s}(P$ $=0.0175$ ). STR (Fig. $3 E$ ) was $67.4 \pm 3.4 \%$ at $15 \mathrm{~s}$ and 

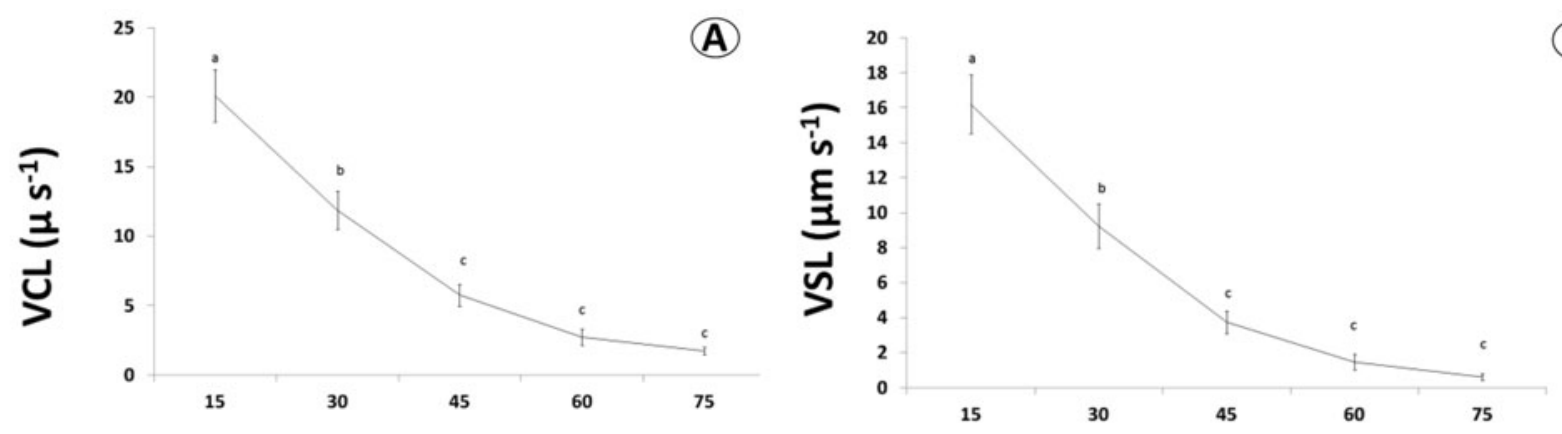

(B)
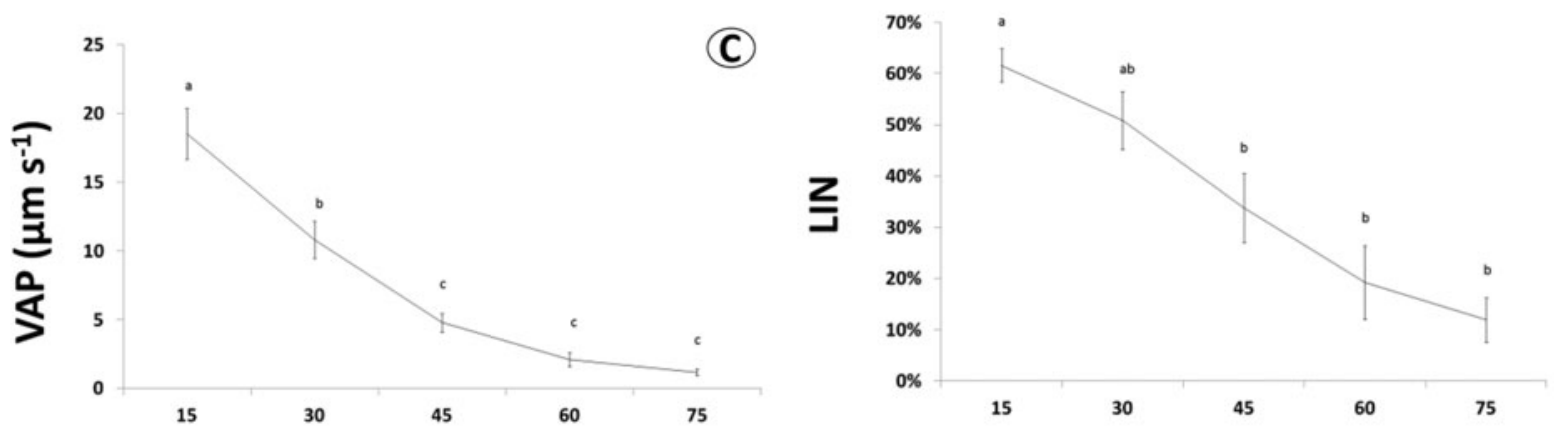

(D)
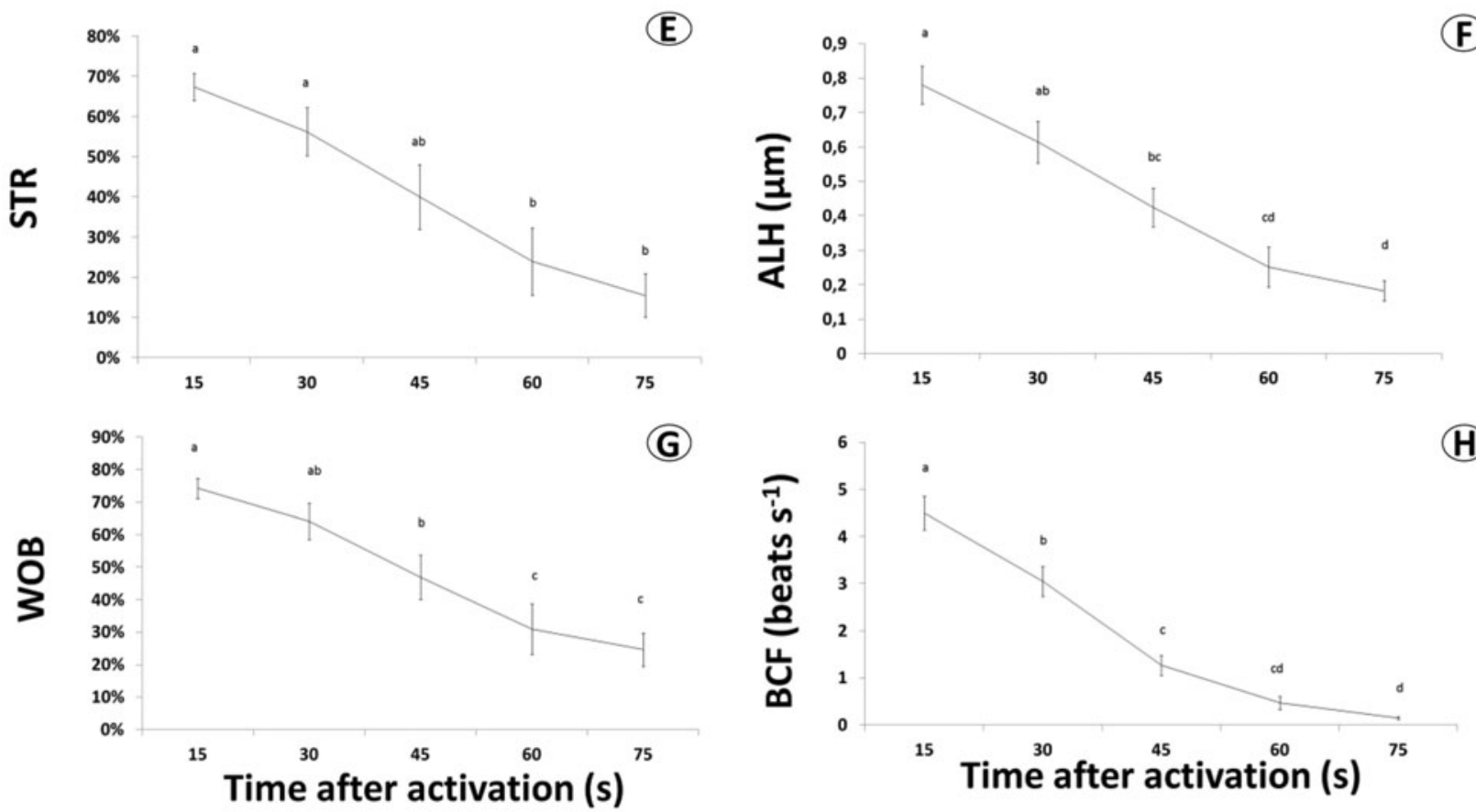

Figure 3 Parameters related to sperm motility of Astyanax altiparanae. Curvilinear velocity (VCL) $(A)$, progressive linear velocity $(\mathrm{VSL})(B)$, average velocity of trajectory (VAP) (C), linearity (LIN) $(D)$, straightness (STR) (E), amplitude of lateral head (ALH) $(F)$, wobble (WOB) $(G)$ and beat cross-frequency $(B C F)(H)$ were measured at $15 \mathrm{~s}, 30 \mathrm{~s}, 45 \mathrm{~s} 60 \mathrm{~s}$ and $75 \mathrm{~s}$ post-activation.

decreased only at $60 \mathrm{~s}$ to $23.9 \pm 8.4 \%(P=0.0012)$. Wobble (WOB) (Fig. 3G) decreased significantly from $74.2 \pm 3.1 \%$ at $15 \mathrm{~s}$ to $46.9 \pm 6.8 \%$ at $45 \mathrm{~s}(P=0.0280)$.

\section{Ultrastructural analysis of oocytes}

Astyanax altiparanae oocytes presented several grooves surrounding the micropyle (Fig. $4 A-F$ ). Such grooves were observed under the stereomicroscope after egg hydration (Fig. $4 A$ ) and also by scanning electron microscopy (SEM) (Fig. 4B-F). The micropyle presented an approximate diameter of $7.57 \mu \mathrm{m}$. The average length of grooves from the micropyle in inactivated oocytes was $257,111 \mu \mathrm{m}$. The diameter of the oocyte before activation was $695,119 \pm 49.5 \mu \mathrm{m}$, and after then was 1,170,909 $\mu \mathrm{m}$. Interestingly, the grooves were 

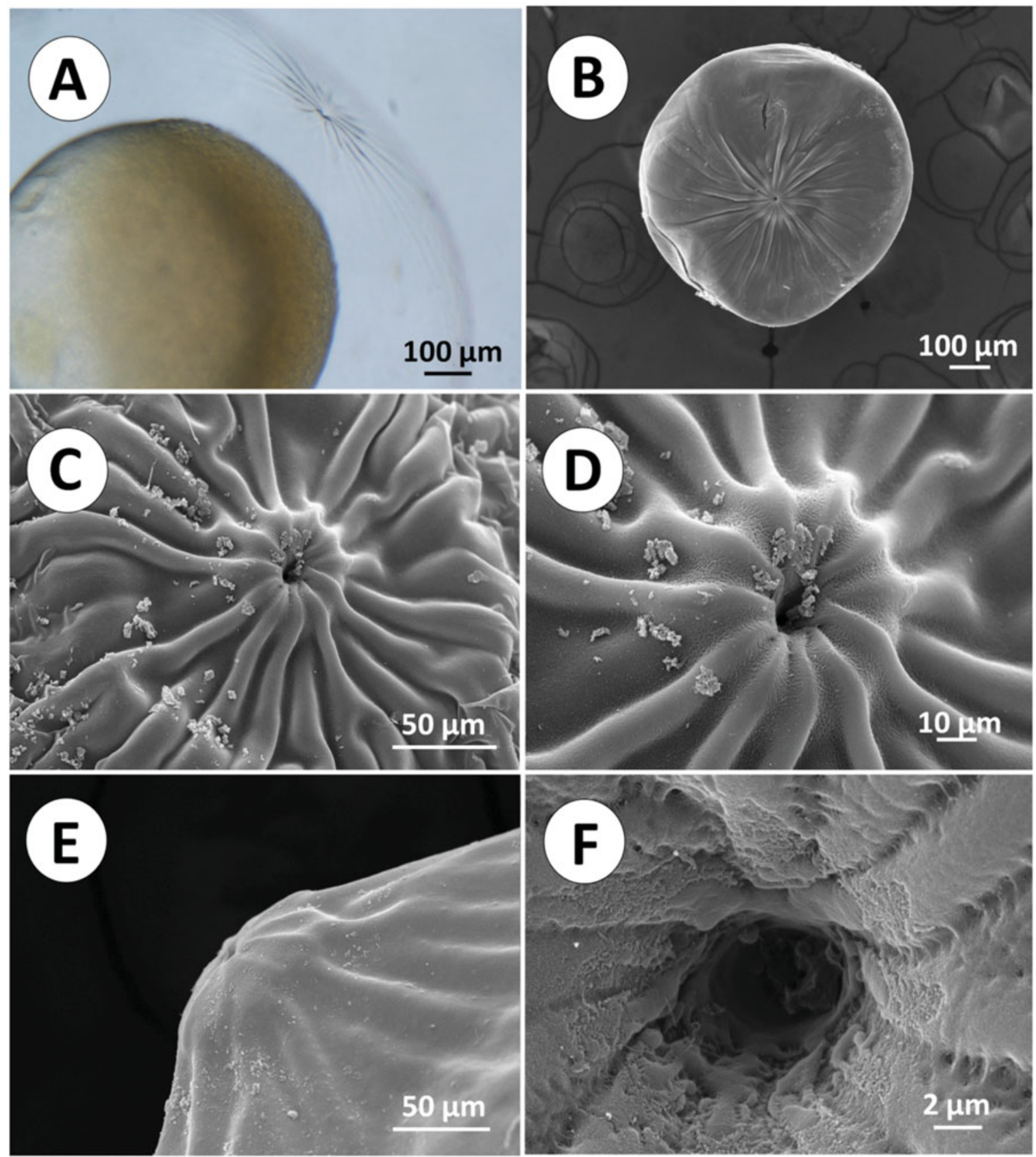

Figure 4 Micropylar region of Astyanax altiparanae in fertilized $(A)$ and unfertilized oocytes $(B-F)$. In $(A)$, developing embryo at blastula stage with chorion after hydration, showing the location of the grooves. General viewing of oocyte showing the micropyle surrounded by grooves by standard error of the mean (SEM) (B). Grooves conformation and a 'ridge' containing the micropyle in the central area $(C)$. Detail of the ridge area containing the micropyle $(D)$. Lateral view of the ridge $(E)$. Micropylar channel $(F)$.

centred in the micropyle region in which there is a projection giving rise to a central 'ridge' (Fig. $4 A$ ).

\section{Discussion}

In fish, several sperm parameters correlated positively with successful fertilization, such as velocity, motility and beating frequency (which is also indicative of velocity) (Kime et al., 2001; Casselman et al., 2006; Gasparini et al., 2010; Galego et al., 2013), spermatozoon size (Gomendio \& Roldan, 2008), sperm viability (Hunter \& Birkhead, 2002). However, many authors indicated sperm velocity as the main factor affecting fertilization (Gage et al., 2004; Hosken et al., 2008; Rudolfsen et al., 2008; Gasparini, et al., 2010). In freshwater teleosts, 
sperm motility is limited to a few seconds after activation (30-50 s for most species, see Cosson, 2004). According to Tuset et al. (2008), fertilization success was related to the following variables: duration of sperm movement, linearity of movement, and sperm concentration.

Astyanax altiparanae spermatozoa remain motile for longer periods presenting good fertilization ability as expressed by sperm parameters. This characteristic improves the fertilization ability as the spermatozoa may have a chance to search for the micropyle for a longer period.

Regarding oocytes, the diameter is also related to fertilization as larger oocytes present an increased area in which sperm will need to seek the micropyle. Such fertilization efficacy is mainly expressed via the insemination dose (i.e. spermatozoa:oocyte ratio). A positive correlation was found within teleost species regarding oocyte diameter such as the Esox lucius (diameter of the oocyte $=2000 \mu \mathrm{m}$, inseminating dose $=700,000 \mathrm{sptz}$ oocyte ${ }^{-1}$, Marciel, 1981), Brycon insignis (diameter of the oocyte $=1300 \mu \mathrm{m}$, insemination dose $=314,481$ spermatozoa per oocyte, Shimoda et al., 2007), Oncorhynchus mykiss (diameter of the oocyte = $4000 \mu \mathrm{m}$, inseminating dose $=200,000$ spermatozoa per oocyte; Silveira et al., 1988), Hippoglossus (diameter of the oocyte $=3000 \mu \mathrm{m}$, inseminating dose $=$ 1,600,000 spermatozoa per oocyte; Suquet et al., 1995), Scophthalmus maximus (diameter of the oocyte $=1000$ $\mu \mathrm{m}$, insemination dose $=6000$ spermatozoa per oocyte; Suquet et al., 1995) and in our study species the diameter is also reduced (diameter of the oocyte $=$ $695,119 \mu \mathrm{m}$, insemination dose $=2.390$ spermatozoa per oocyte).

Other factors may affect the fertilization ability. Yanagimachi et al. (2013) reported chemical attractants in the micropylar region that facilitates the sperm entrance and attempt fertilization in teleost fishes and insects. The authors suggested that although the sperm moved randomly in the water, a previous contact with the oocyte made the sperm to move on the oocyte surface and seek the micropyle. This type of sperm orientation is not unique to fish and has long been reported for other species and named as a contact reaction of spermatozoa (Lillie, 1919). In the medaka Oryzias latipes, similar attractants were reported by Iwamatsu et al. (2005), although Ishijima et al. (1993) did not observe any alteration in sperm velocity close to the micropylar area.

The number of micropyles and its diameter may also affect fertilization success. Teleosts present a single micropyle that differs from the multimicropylar oocytes within condrosteans (Linhart \& Kudo, 1997). Theoretically, the diameter of the micropyle may affect sperm entrance because a larger micropyle increases the probability of sperm entrance. How- ever, teleosts present low variation in micropyle diameter as in Oryzias latipes $(5.30 \mu \mathrm{m}$; Ishijima et al., 1993), Fundulus heteroclitus (4-5 $\mu$ m; Kuchnow \& Scott, 2006), Saurida elongate (3.7 $\mu \mathrm{m}$; Hirai, 1988), Oplegnathus fasciatus (6.2 $\mu \mathrm{m}$; Hirai, 1988), Oncorhynchus mykiss (4 $\mu \mathrm{m}$; Yanagimachi et al., 1992) and the Astyanax altiparanae, in the present study (7.57 $\mu \mathrm{m})$. As far as we know, there is no relationship between the diameter of the micropyle and fertilization success.

In other species, including Barbus conchonius (Amanze \& Iyengar, 1990) structures called 'ridges' and 'stretch marks' were found in the micropylar area that were similar to the grooves found in Astyanax altiparanae and also in Astyanax bimaculatus (Rizzo et al., 2002). Such structures may physically guide the sperm to the micropyle and this mechanism may improve fertilization success. In the grass goby Zosterisessor ophiocephalus, follicular cells produce a forest of attachment filaments up to $600 \mu \mathrm{m}$ in length that surround the micropyle (Giulianini \& Ferrero, 2000) and is also a mechanism for sperm guidance.

In our study, it was also possible to describe a conical elevation on the central region of those grooves that surrounded the micropyle. Zebrafish Brachydanio rerio eggs also presented such a ridge in the micropylar area, as described by Hart (1990). In this study we found for the first time a combination of both structures. The ridges and grooves indicated that the sperm is guided by grooves to a ridge where the micropyle is found in the central region. In this mechanism, hydration physically blocks oocyte fertilization by two mechanisms. The first mechanism is similar to that in other species in which the micropyle is separated from the surface of the oocyte by increasing the perivitelline space. In the second mechanism, increase in the perivitelline space will reduce the area that contains the grooves, therefore reducing sperm guidance. The latter mechanism was also observed by Riehl \& Patzner (1991) in catfish Sturisoma aureum, in which the grooves occupied almost the entire region of the oocyte.

In conclusion, we found that Astyanax altiparanae has one of the lowest insemination dose values among teleosts described in the literature. This fertilization efficacy is explained by: (1) reduced oocyte diameter; (2) increased micropyle diameter; (3) increased duration of sperm motility; and (4) the presence of grooves on the surface of the oocyte that guide sperm to the micropyle. In addition, we found a new morphology in oocytes that combined grooves and the micropyle ridge. Our findings are innovative in our species of study and bring new perspectives on the fertilization ability and subsequent insemination dose for fish with external fertilization. 


\section{Acknowledgements}

We acknowledge CEPTA-ICMBio for kindly providing facilities and experimental fish and the Faculty of Medicine of Ribeirão Preto, University of São Paulo (USP), Brazil for the scanning electron microscopy analysis.

\section{Funding}

This work was supported by the São Paulo Research Foundation (FAPESP, Young Investigators Award Grant \#2010/17429-1, Young Researcher Scholarship \#2011/11664-1, and MSc Scholarship \#2012/18961-4).

\section{References}

Amanze, D. \& Iyengar, A. (1990). The micropyle: a sperm guidance system in teleost fertilization. Development 109, 495-500.

Bobe, J. \& Labbé, C. (2010). Egg and sperm quality in fish. Gen. Comp. Endocrinol. 165, 535-48.

Casselman, S.J., Schulte-Hostedde, A.I. \& Montgomerie, R. (2006). Sperm quality influences male fertilization success in walleye (Sander vitreus). Can. J. Fish. Aqua. Sci. 63, 211925.

Cosson, J. (2004). The ionic and osmotic factors controlling motility of fish spermatozoa. Aquacult. Int. 12, 69-85.

Coward, K., Bromage, N.R., Hibbitt, O. \& Parrington, J. (2002). Gamete physiology, fertilization and egg activation in teleost fish. Rev. Fish Biol. Fish. 12, 33-58.

Gage, M.J.G., Macfarlane, C.P., Yeates, S., Ward, R.G., Searle, J.B. \& Parker, G.A. (2004). Spermatozoal traits and sperm competition in Atlantic salmon: relative sperm velocity is the primary determinant of fertilization success. Curr. Biol. 14, 44-7.

Galego, V., Pérez, L., Asturiano, J.F. \& Yoshida, M. (2013). Relationship between spermatozoa motility parameters, sperm/egg ratio, and fertilization and hatching rates in pufferfish (Takifugu niphobles). Aquaculture 416-417, 238-43.

Garutti, V. \& Britski, H.A. (2000). Descrição de uma espécie nova de Astyanax (Teleostei: Characidae) da bacia do alto rio Paraná e considerações sobre as demais espécies do gênero na bacia. Comum. Mus. Ciênc. Tecnol. PUCRS. Sér. Zool. Porto Alegre, 13, 65-88.

Gasparini, C., Simmons, L.W., Beveridge, M. \& Evans, J.P. (2010). Sperm swimming velocity predicts competitive fertilization success in the green swordtail Xiphophorus helleri. PLoS One 5, 1-5.

Ginsburg, A.S. (1961). The block to polyspermy in sturgeon and trout with special reference to the role of cortical granules (aleveoli). J. Embryo Exp. Morphol. 9, 173-90.

Ginsburg, A.S. (1963). Sperm-egg association and its relationship to the activation of the egg in Salmonid fishes. J. Embryo Exp. Morphol. 11, 13-33.

Giulianini, P.G. \& Ferrero, E.A. (2000). Ultrastructural aspects of the ovarian follicle and egg envelope of the sea-grass goby Zosterisessor ophiocephalus (Osteichthyes, Gobiidae). Ital. J. Zool. 68, 29-37.

Gomendio, M. \& Roldan, E.R.S. (2008). Implications of diversity in sperm size and function for sperm competition and fertility. Int. J. Dev. Biol. 52, 439-47.

Hart, N.Y. (1990). Fertilization in teleost fishes: Mechanisms of sperm-egg interactions. Int. Rev. Cyto. 121, 1-66.

Hirai, A. (1988). Fine structures of the micropyles of pelagic eggs of some marine fishes. Japan J. Ichthyol. 35, 351-7.

Hirohashi, N., Kamei, N., Kubo, H., Sawasa, H., Matsumoto, M. \& Hoshi, M. (2008). Egg and sperm recognition systems during fertilization. Dev. Growth Diff. 50, S221-38.

Hosken, D.J., Taylor, M.L., Hoyle, K., Higgins, S. \& Wedell, N. (2008). Attractive males have greater success in sperm competition. Curr. Biol. 18, 553-4.

Hunter, F.M. \& Birkhead, T.R. (2002). Sperm viability and sperm competition in insects. Curr. Biol. 12, 121-3.

Ishijima, S., Hamaguchi, Y. \& Iwamatsu, T. (1993). Sperm behavior in the micropyle in the medaka egg. Zool. Sci. 10, 179-82.

Iwamatsu, T., Ishijima, S. \& Nakashima, S. (2005). Movement of spermatozoa and changes in micropyles during fertilization in medaka eggs. J. Exp. Zool. 266, 57-64.

Kime, D.E., Van Look, K.J.W., McAllister, B.G., Huyskens, G., Rurangwa, E. \& Ollevier, F. (2001). Computer-assisted sperm analysis (CASA) as a tool for monitoring sperm quality in fish. Comp. Biochem. Physiol. 130, 425-33.

Kuchnow, K.P. \& Scott, J.R. (2006). Ultrastructure of the chorion and its micropyle apparatus in the mature Fundulus heteroclitus (Walbaum) ovum. J. Fish Biol. 10, 197201.

Lillie, F.R. (1919). Problems of Fertilization. Chicago: Univ. of Chicago Press, pp. 98-99.

Linhart, O. \& Kudo, S. (1997). Surface ultrastructure of paddlefish eggs before and after fertilization. J. Fish Biol. 51, 573-82.

Mansour, N., Lahnsteiner, F. \& Patzner, R.A. (2002). The spermatozoon of the African catfish: fine structure, motility, viability and its behaviour in seminal vesicle secretion. J. Fish Biol. 60, 545-60.

Marciel, J. (1981). Contrôle de la reproduction et gestions dês gamètes de quelques espèces de poissons téléostéens. Lyons: École Pratique des hautes Études. $132 \mathrm{ff}$.

McMillan, D.B. (2007). Fish Histology: Female Reproductive Systems. University of Western Ontario, Canada. Springer.

Morisawa, S. \& Morisawa, M. (1986). Acquisition of potential for sperm motility in rainbow trout and chum salmon. J. Exp. Biol. 126, 89-96.

Riehl, R. \& Patzner, R.A. (1991). Breeding, structure, and larval morphology of the catfish Sturisoma aureum (Steindachner) (Teleostei, Loricariidae). J. Aquac. Aquat. Sci. 6, 1-6.

Rizzo, E., Sato, Y., Barreto, B.P. \& Godinho, H.P. (2002). Adhesiveness and surface patterns of eggs in neotropical freshwater teleosts. J. Fish Biol. 61, 615-32.

Rudolfsen, G., Figenschou, L., Folstad, I. \& Kleven, O. (2008). Sperm velocity influence paternity in the Atlantic cod (Gadus morhua L.). Aquacul. Res. 39, 212-6.

Rurangwa, E., Roelants, I., Huyskens, G., Ebrahimi, M., Kime, D.E. \& Ollevier, F. (1998). The minimum effective spermatozoa: egg ratio for artificial inseminating and the 
effects of mercury on sperm motility and fertilization ability in Clarias gariepinus. J. Fish Biol. 53, 402-13.

Scott, A.P. \& Baynes, S.M. (1980). A review of the biology, handling and storage of salmonid spermatozoa. J. Fish Biol. 17, 707-39.

Shimoda, E., Andrade, D.R., Vidal, Júnior, M.V., Godinho, H.P. \& Yasui, G.S. (2007). Determinação da razão ótima de espermatozoides por ovócitos de piabanha Brycon insignis (Pisces: Characidae). Arq. Bras. de Med. Vet. Zootec. 59, 87782.

Silveira, W.F., Kavamoto, E.T., Rigolino, M.G. \& Tabata, Y.A. (1988). Fertilidade do sêmen da truta arco-íris, Salmo irideus Gibbons, em diferentes concentrações de espermatozoides por óvulo. Bol. Inst. Pesca 15, 51-7.

Stolz, J.A. \& Neff, B.D. (2006). Sperm competition in a fish with external fertilization: the contribution of sperm number, speed and length. J. Evol. Biol. 19, 1873-81.

Suquet, M., Billard, R. \& Cosson, J. (1995). Artificial inseminating in turbot (Scophthalmus maximus): determination of the optimal sperm to egg ratio and time of gamete contact. Aquaculture 133, 83-90.

Tuset, V.M., Dietrich, G.J., Wojtczak, M., Slowinska, M., Monserrat, J. \& Ciereszko, A. (2008). Relationship between morphology, motility and fertilization capacity in rainbow trout (Oncorhynchus mykiss) spermatozoa. J. Appl. Ichthyol. 24, 393-7.

Viveiros, A.T.M. \& Godinho, H.P. (2009). Sperm quality and cryopreservation of Brazilian freshwater fish species: a review. Fish. Physiol. Biochem. 35, 137-50.

Yanagimachi, R., Cherr, G.N., Pillai, M.C. \& Baldwin, J.D. (1992). Factors controlling sperm entry into the micropyle of salmonid and herring eggs. Dev. Growth Diff. 34, 447-61.

Yanagimachi, R., Cherr, G., Matsubara, T., Andoh, T., Harumi, T., Vines, S, C., Pillai, M., Griffin, F, Matsubara, H., Weatherby, T. \& Kenneth, K. (2013). Sperm attractant in the micropyle region of fish and insect eggs. Biol. Reprod. 88, 47.

Yasui, G.S., Arias-Rodrigues, L., Fujimoto, T. \& Arai, K. (2009). A sperm cryopreservation protocol for the loach Misgurnus anguillicaudatus and its applicability for other related species. Anim. Repr. Sci. 116, 335-45.

Yasui, G.S., Senhorini, J.A., Shimoda, E., Pereira-Santos, M., Nakaghi, L.S.O., Fujimoto, T., Arias-Rodrigues, L. \& Silva, L.A. (2015). Improvement of gamete quality and its shortterm storage: an approach for biotechnology in laboratory fish. Animal 9, 464-70. 